\title{
Nectar trichome structure of aquatic bladderworts from the section Utricularia (Lentibulariaceae) with observation of flower visitors and pollinators
}

\author{
Bartosz J. Płachno ${ }^{1} \cdot$ Małgorzata Stpiczyńska ${ }^{2} \cdot$ Lubomír Adamec $^{3} \cdot$ Vitor Fernandes Oliveira Miranda $^{4} \cdot$ Piotr Świątek $^{5}$
}

Received: 20 November 2017 / Accepted: 26 January 2018 / Published online: 5 February 2018

(C) The Author(s) 2018. This article is an open access publication

\begin{abstract}
In Utricularia, the flower spur is a nectary and in this organ, nectar is produced and stored. This study aimed to examine the structure of the nectary trichomes in four Utricularia species (Utricularia vulgaris L., U. australis R.Br., U. bremii Heer and U. foliosa L.) from the generic section Utricularia. We have investigated whether species with different spur morphology had similar spur anatomy and nectary trichome structure. In Utricularia flowers, nectar is produced by spur capitate trichomes (sessile or stalked). Our results showed that regardless of the various spur morphology, trichomes have similar architecture and ultrastructure. Head cells of these trichomes are transfer cells with an eccrine nectar secretion. Examined species differed in the micromorphology of papillae in spurs. The fly Eristalis tenax was found to be a pollinator of U. vulgaris. Small Halictidae bees seem to be pollinators of $U$. foliosa.
\end{abstract}

Keywords Bladderwort · Sect. Utricularia · Lentibulariaceae · Carnivorous plant · Floral micromorphology · Nectar · Spur · Pollination $\cdot$ Nectary ultrastructure $\cdot$ Entomophily $\cdot$ Trichomes

\section{Introduction}

In flowering plants, typical flower spurs are tubular outgrowths of perianth organs which contain nectar for pollinators. The nectary spur has been of interest to researchers for a very long time; e.g. after analysing of the spur of orchid

Handling Editor: Alexander Schulz

Bartosz J. Płachno

bartosz.plachno@uj.edu.pl

1 Department of Plant Cytology and Embryology, Jagiellonian University in Kraków, 9 Gronostajowa St, 30-387 Cracow, Poland

2 Botanic Garden, Faculty of Biology, University of Warsaw, Al. Ujazdowskie 4, 00-478 Warsaw, Poland

3 Section of Plant Ecology, Institute of Botany of the Czech Academy of Sciences, Dukelská 135, -37982 Třeboň, CZ, Czech Republic

4 Faculdade de Ciências Agrárias e Veterinárias, Jaboticabal, Departamento de Biologia Aplicada à Agropecuária, Universidade Estadual Paulista (Unesp), São Paulo, Brazil

5 Department of Animal Histology and Embryology, University of Silesia in Katowice, 9 Bankowa St, 40-007 Katowice, Poland
Angraecum sesquipedale, Darwin (1862) proposed the coevolution of the length of a nectar spur and its pollinator's tongue. Nectary spur characters are strongly associated with a type of pollinator, and this organ has evolved multiple times across flowering plants (Hodges 1997). After a phylogenetic analysis of the pollination evolution syndrome in Aquilegia, Whittall and Hodges (2007) proposed a significant evolutionary trend for increasing the nectary spur length during directional shifts to pollinators with longer tongues. According to Box et al. (2011), spurs could have evolved in angiosperms by changes in regulatory $K N O X$ gene expression. Changes in spur characters are the true evolutionary innovations underlying the rapid radiation of some genera or families including Lentibulariaceae (e.g., Hodges and Arnold 1995; Hodges 1997; Puzey et al. 2012).

Most Utricularia species (Lentibulariaceae family) have well-developed spurs which are outgrowths of the lower corolla lip (Taylor 1989). However, in some species, the spur may be reduced in size compared to that of other corolla parts (as in U. dunlopii; Płachno et al. 2016) or the spur region may be only shallowly saccate as in $U$. rigida Benj. and U. tetraloba P.Taylor (Taylor 1989). In contrast to other Utricularia species, Utricularia simmonsii Lowrie, Cowie \& 
Conran, which is probably the smallest species in the genus, lacks a spur entirely (Lowrie et al. 2008).

Observations of nectar production in Utricularia are scare. Hobbhahn et al. (2006) were the first to prove nectar production in three terrestrial Utricularia species belonging to the subgenus Bivalvaria and presented detailed data on nectar volumes and sugar concentrations. Vogel (pers. comm. in Hobbhahn et al. 2006) observed nectar in some South American Utricularia species. However, according to Jérémie (1989), the autogamous Utricularia alpina does not produce nectar. In contrast, Abrahamczyk et al. (2017) not only recorded nectar in this species but also estimated nectar sugar concentrations. Nectar was recorded in the spurs of Utricularia reniformis A.St.Hil. (Clivati et al. 2014; Abrahamczyk et al. 2017), Utricularia nephrophylla Benj. (Abrahamczyk et al. 2017) and U. nelumbifolia (Płachno et al. 2017b). Hobbhahn et al. (2006) pointed out that further research was needed to determine the frequency of nectar occurrence within the genus as well as the possible correlations of nectar production with the reproductive system.

This study aimed to examine the structure of the flower nectary trichomes in four Utricularia species from the section Utricularia using light microscopy and scanning and transmission electron microscopy. We investigated whether species with different spur morphology have similar spur anatomy and nectary trichome structure. To proper understanding Utricularia flower function in relation to its morphology and nectar secretion, additionally, we investigated flower visitors and potential pollinators.

\section{Material and methods}

\section{Plant material}

The species used in this study included Utricularia vulgaris L., U. bremii Heer, U. australis R.Br. and U. foliosa L. Utricularia vulgaris was kept in the collection of aquatic carnivorous plants in the Institute of Botany of the Czech Academy of Sciences at Třeboň, S Bohemia, Czech Republic. Cultivation conditions are detailed by Adamec and Poppinga (2016). Open flowers were observed in outdoor conditions in order to record flower visitors or pollinators during various seasons $(2012,2017)$. The insects were photographed using a Nikon D810 and an Olympus SP510UZ digital camera. Trapped insects were analysed using scanning electron microscopy (SEM) to check if $U$. vulgaris pollen grains occurred on insect surfaces.

Flowers of $U$. bremii were collected from a shallow sandpit Cep I in Suchdol nad Lužnicí, S Bohemia, Czech Republic, in 2016 and 2017. Flowers of $U$. australis were collected from populations in Silesia, Poland, in 2010 and also from the shallow sand-pit Cep I in Suchdol nad Lužnicí in 2016 and 2017.
Flowers of $U$. australis originating from N.S.W, Australia, were taken from the collection of the Institute of Botany at Třeboň. Utricularia foliosa flowers were collected from a natural site in Mogi das Cruzes Municipality, São Paulo State, Brazil. The herbarium voucher is deposited at the JABU Herbarium (Universidade Estadual Paulista UNESP/ FCAV). Plants with flowers were observed under field conditions to record flower visitors or pollinators during all the seasons (January to December) and at least in 2 months of a season. The insects were photographed using a camera Sony Cybershot DSC-HX1. Trapped insects were again analysed using SEM to check whether Utricularia pollen grains were present.

\section{Floral structure and histochemical investigations}

The distribution of the secretory glandular trichomes was determined by examining whole flowers (corollas) using a Nikon SZ100 stereoscopic microscope. Floral parts, namely the spurs, were examined using light microscopy (LM), scanning electron microscopy (SEM) and transmission electron microscopy (TEM) as follows. Firstly, the tissue of the spurs was examined during anthesis (in $U$. vulgaris also in young closed flowers). Pieces of the floral tissues (spurs) were excised and fixed in a mixture of $2.5 \%$ glutaraldehyde with $2.5 \%$ formaldehyde in a $0.05 \mathrm{M}$ cacodylate buffer (Sigma; $\mathrm{pH} 7.2$ ) overnight or for several days, washed three times in a $0.1 \mathrm{M}$ sodium cacodylate buffer and post-fixed in a $1 \%$ osmium tetroxide solution at room temperature for $1.5 \mathrm{~h}$. Dehydration using a graded ethanol series, infiltration and embedding using an epoxy embedding medium kit (Fluka) followed. Following polymerisation at $60{ }^{\circ} \mathrm{C}$, sections were cut at $70 \mathrm{~nm}$ for TEM using a Leica ultracut UCT ultramicrotome, stained with uranyl acetate and lead citrate (Reynolds 1963) and examined using a Hitachi H500 transmission electron microscope at an accelerating voltage of $75 \mathrm{kV}$.

Semi-thin sections $(0.9-1.0 \mu \mathrm{m}$ thick) were prepared for LM and stained for general histology using aqueous methylene blue/azure II (MB/AII) for 1-2 min (Humphrey and Pittman 1974) and examined with an Olympus BX60 light microscope. Some material for semi-thin sections was fixed in ethanol/acetic acid (3:1 v/v). For each species (U. vulgaris, $U$. bremii), the 10 trichomes were measured. The mean values for trichomes of these species were given in the "Results" section.

For SEM, the representative floral parts were fixed (as above or in ethanol/acetic acid 3:1 v/v) and later dehydrated and subjected to critical-point drying using liquid $\mathrm{CO}_{2}$. They were then sputter-coated with gold and examined at an accelerating voltage of $20 \mathrm{kV}$ using a Hitachi S-4700 scanning electron microscope (Hitachi, Tokyo, Japan), which is housed in the Institute of Geological Sciences, Jagiellonian University in Kraków). 


\section{Results}

\section{Utricularia vulgaris (Figs. 1, 2, 3, 4 and 5)}

\section{General flower morphology and nectary trichome structure}

The corolla of $U$. vulgaris was yellow with reddish-brown nectar marks on the palate. The lower corolla lip formed a platform, but its margins were U-shaped deflexed. The lower lip was not firmly appressed to the upper lip, there was a slit and generative structures were visible (Fig. 1a). The spur was oriented directly downwards from the lower corolla lip at an acute angle. Nectar was observed inside the spur, forming micro-droplets (Fig. 1b). Nectar trichomes occurred on the internal abaxial side of the spur (Fig. 1c), and nectary stomata were absent.

In a transverse section, the wall of the spur was composed of several cell layers: the internal epidermis, a few layers (2-3) of parenchyma cells and the outer epidermis (Fig. 2a, b). The parenchyma cells were non-glandular. Relatively large intercellular spaces occurred between the parenchyma cells. The parenchyma cells had numerous plastids with large starch grains. Collateral vascular bundles occurred in the ground parenchyma (Fig. 2c), each containing both xylem and phloem elements. Internal epidermis formed papillae, which were unicellular with a smooth surface (Fig. 2d). They were highly vacuolated and had numerous plastids in their cytoplasm.

Glandular spur trichomes were composed of a single basal cell which formed a unicellular stalk (length $21 \mu \mathrm{m}$ ), pedestal cell (barrier cell, mean length $=17 \mu \mathrm{m}, n=10)$ (Fig. 2b) and a multi-celled head (mean length $=21 \mu \mathrm{m}, n=10$, mean diameter $=47 \mu \mathrm{m}, n=10$; Figs. $2 \mathrm{~b}$ and $3 \mathrm{a}$ ). However, part of the trichomes had a two-celled stalk, which consisted of a basal cell and an additional cell (Fig. 2d, e). The pedestal cell and the head cells were different in vacuolisation and the degree of cytoplasm density from the stalk cells (Fig. 2b, e).

The basal cell was highly vacuolated and most of the cytoplasm with the usual organelles was located in the upper part of the cell near the pedestal cell or the additional stalk cell. The nucleus of the basal cell was surrounded by numerous plastids. The lateral wall of the basal cell developed a cuticle in the place where it was not connected with other cells. Similarly, the lateral wall of the additional stalk cell developed a distinct cuticle. The additional stalk cell was more or less cylindrically shaped. Numerous plasmodesmata occurred in the transverse walls between the stalk cell and the pedestal cell as well as between the additional stalk cell and the pedestal cell (Fig. 2f). The pedestal cell had a thick radial wall, which was impregnated with cutin (Figs. $2 \mathrm{f}$ and $3 \mathrm{a}$ ). Most of the cytoplasm, with the nucleus and the usual organelles (mitochondria, plastids, and endoplasmic reticulum), were located in the upper part of the cell near the head cells (Fig. 3a). Numerous plasmodesmata occurred in the transverse walls between the pedestal cell and the terminal cells. The protoplasts of the head cells were electron-dense and had a prominent nucleus containing a paracrystalline protein inclusion (Fig. 3b). The cell wall ingrowths arose from the inner surface of the outer cell walls (Fig. 3b) as well as from the inner walls between the head cells. Plastids were numerous and were dumbbell- or cubeshaped (Fig. 3a) There were also multivesicular bodies (MVBs) present. Flocculent electron-dense material was present in the vacuoles (Fig. 3b). Mitochondria with welldeveloped cristae and profiles of rough endoplasmic reticulum (RER) were common in the cytoplasm of the head cells. Dictyosomes were small and not hypertrophied. The thick cuticle (Fig. 3b) frequently became distended and separated from the cell walls of the head cells on the apex of the head (Fig. 2e). Small cuticle pores together with micro-droplets of secretions were observed (Fig. 3c).

\section{Floral visitors and pollinators}

Flowers of Utricularia vulgaris were visited by females of a Common Drone Fly Eristalis tenax (Linnaeus, 1758); family Syrphidae (Fig. 4a-c) and a small bee Lasioglossum sp.; family Halictidae (Fig. 5a, b). Inside the flowers, undetermined members of Thysanoptera were observed. Aphids (Rhopalosiphum nymphaeae L.) occurred mainly on the external parts of inflorescences, and sometimes, aphids also were seen in the flowers (not shown).

A specimen of the large fly Eristalis tenax used the lower lip as a landing platform and later forced open the two corolla lobes. It entered the corolla tube with the front of its body and fed on the nectar in the spur. During this process, the fly was holding its leg on the expanded-swollen part of the lower lip (limb - the term sensu Taylor 1989, a part of palate sensu us) (Fig. 4a). SEM analysis revealed that Utricularia vulgaris pollen grains occurred on the surface of the Eristalis head and thorax - both on the lateral parts as well as on the insect's back (Fig. 4d, e). Eristalis tenax cleaned its surface after penetrating the flower (Fig. 4c). The Lasioglossum bee penetrated the palate (Fig. 5a), studied the surface of the palate using antennae (Fig. 5a) and later penetrated the corolla tube (Fig. 5b). In contrast to Eristalis tenax, Lasioglossum was not using its strength to penetrate the flower and also did not deform the corolla shape during the visit. Under SEM, we did not observe $U$. vulgaris pollen grains on the surface of the Lasioglossum head and thorax.

\section{Utricularia australis (Fig. 6a-d)}

The corolla of $U$. australis was yellow with reddish-brown nectar marks on the prominent palate (Fig. 6a). In the transverse section, the wall of the spur was composed of several cell layers: internal epidermis, a few layers of parenchyma cells and outer epidermis (Fig. 6b). The parenchyma cells 
Fig. 1 General floral morphology of Utricularia vulgaris. a Floral morphology of $U$. vulgaris from the collection of aquatic carnivorous plants in the Institute of Botany at Třeboň-visible generative structures (arrow). b Opened spur, nectar forms microdroplets. c Section through the spur; nectar trichomes (star); bar $=1 \mathrm{~mm}$
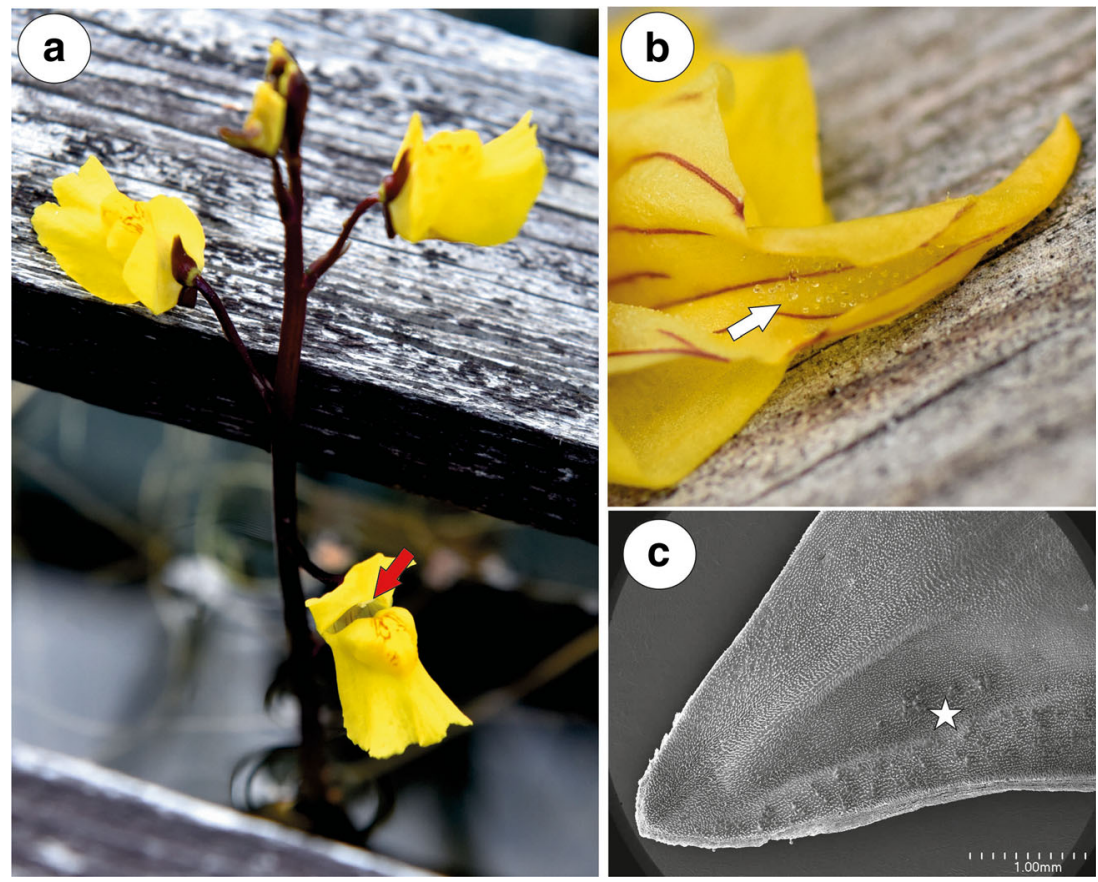

Fig. 2 Morphology and anatomy of Utricularia vulgaris spur. a Part of the section through the spur with glandular trichomes and papillae; bar $=100 \mu \mathrm{m}$. b General structure of the glandular trichome; note that the head cells of the trichomes stain intensely with MB/AII: terminal = head cells $(\mathrm{H})$, pedestal cell $(\mathrm{Pc})$, basal cell $(\mathrm{Bc})$, parenchyma cell $(\mathrm{Pa})$, intercellular spaces (star); bar = $20 \mu \mathrm{m}$. c Part of the section through the spur showing vascular bundle: xylem elements (x), phloem $(\mathrm{Ph}) ;$ bar $=20 \mu \mathrm{m}$. d, e Trichomes with two-celled stalk consisting of the basal cell and the additional cell (Ad), pedestal cell (white arrow) and separated cuticle from the head cells (black arrow); bar $=50 \mu \mathrm{m}(\mathbf{d})$ and $20 \mu \mathrm{m}$ (e). f Part of longitudinal section through basal cell and pedestal cell $(\mathrm{Pc})$, note numerous plasmodesmata (arrows) between these cells; thickened impregnated anticlinal wall of a pedestal cell (star); bar $=1.15 \mu \mathrm{m}$
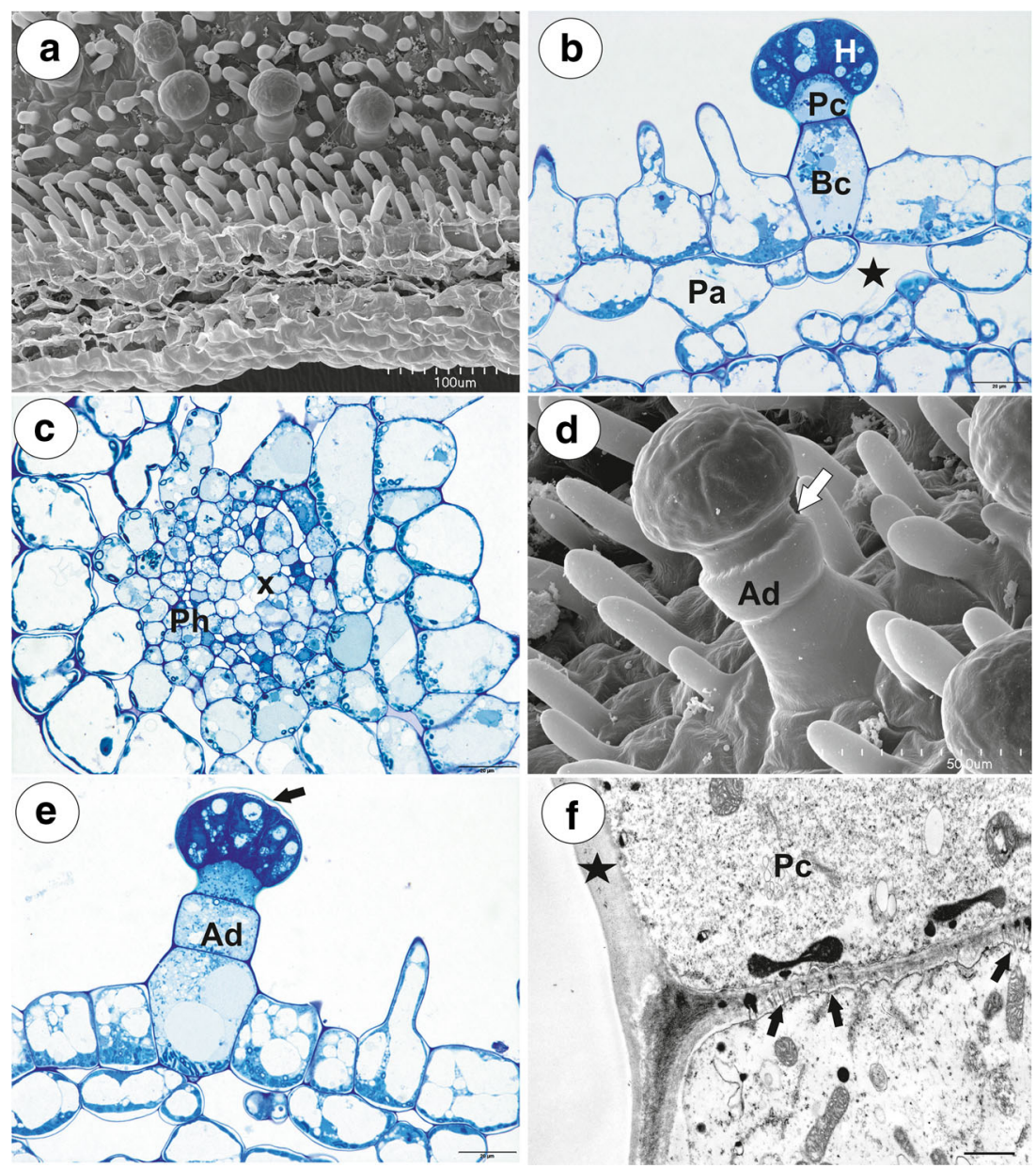
Fig. 3 Ultrastructure of a

glandular trichome from the spur of Utricularia vulgaris. a

Ultrastructure of pedestal (Pc) and terminal cells $(\mathrm{Hc})$; note the welldeveloped labyrinth wall (arrows) in the pedestal cell, plastids (P), mitochondria $(\mathrm{m})$, endoplasmic reticulum $(\mathrm{Er})$, nucleus $(\mathrm{N})$; bar $=$ $1.2 \mu \mathrm{m}$. b Ultrastructure of terminal cells; note the paracrystalline protein inclusion (star) in the nucleus $(\mathrm{N})$, dense cytoplasm with numerous plastids, mitochondria (m). In the vacuoles $(\mathrm{V})$, there is a flocculent electron-dense material. Cell-wall ingrowths (arrows) are on the inner surface of the outer wall; thick cuticle (c); bar $=1.8 \mu \mathrm{m}$. c Cuticle of head cells visible in SEM, note cuticular pores (arrows); bar $=5 \mu \mathrm{m}$
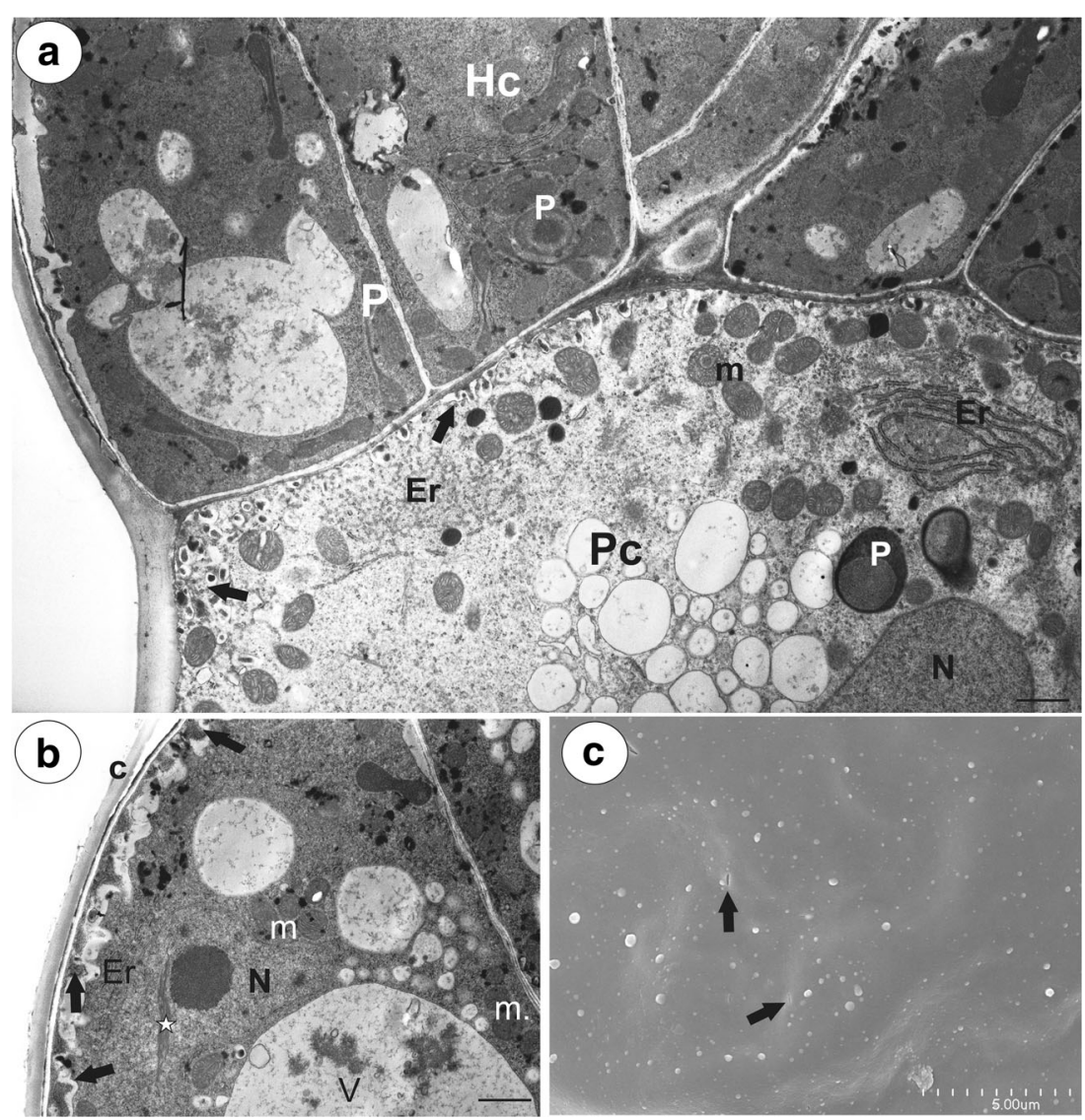

were non-glandular. Very large intercellular spaces occurred between the parenchyma cells (Fig. 6b). Two collateral vascular bundles occurred in the parenchyma, each containing both xylem and phloem elements (not shown). Nectar trichomes occurred on both the abaxial and adaxial spur side (Fig. 6c). These glandular trichomes were composed of a single basal cell which formed the unicellular stalk, the pedestal cell (barrier cell) and a multi-celled head (Fig. 6b). However,
Fig. 4 Pollination of Utricularia vulgaris. a-c Behaviour of Eristalis tenax on $U$. vulgaris flowers. d, e Pollen grains of $U$. vulgaris on the surface of Eristalis tenax; bar $=50 \mu \mathrm{m}$

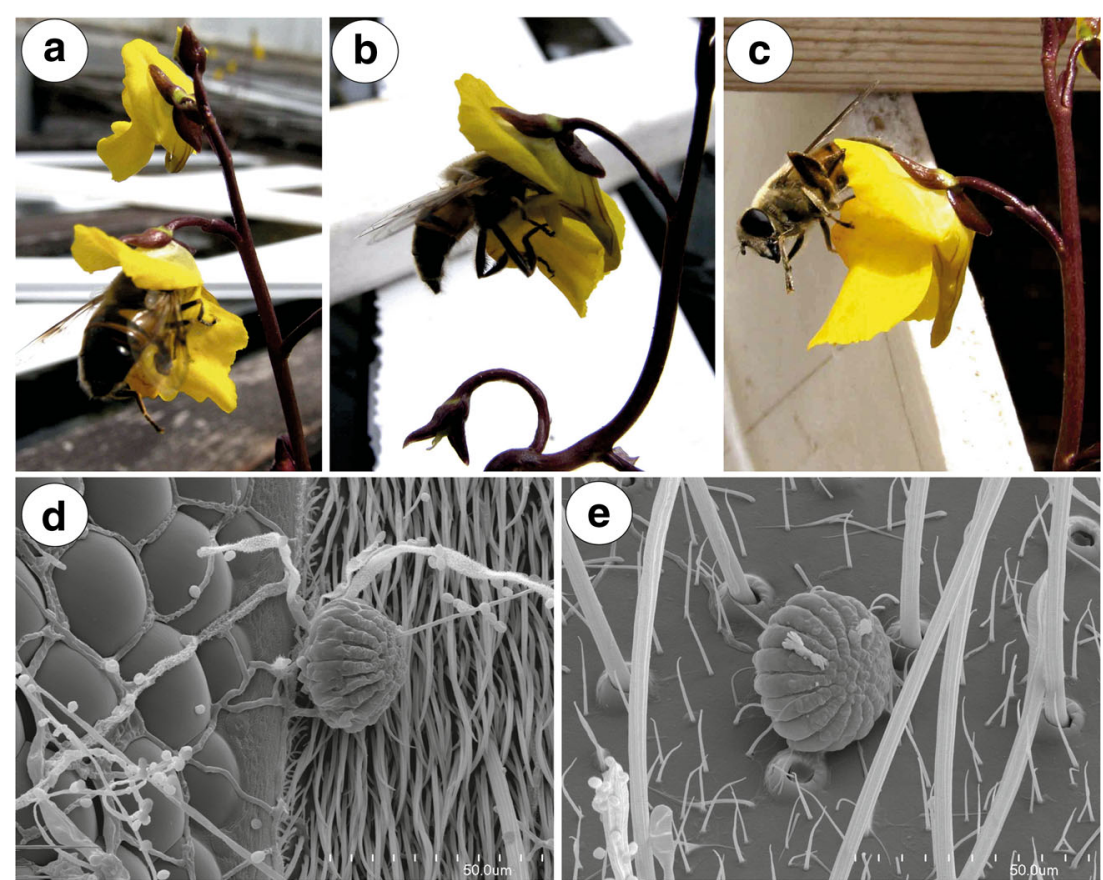


Fig. 5 Visitors on the surface of Utricularia vulgaris flower. a, b Behaviour of bee Lasioglossum sp. on the $U$. vulgaris flower

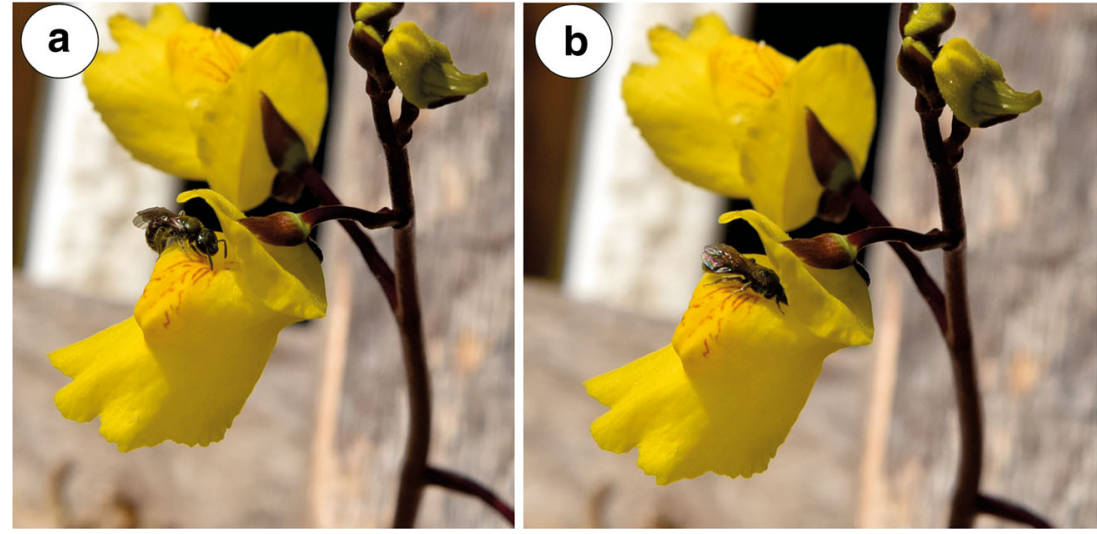

part of the trichomes had the two- or three-celled stalk, which consisted of a basal cell and one or two additional cells (Fig. 6d). Epidermal cells sometimes formed a pedestal for the trichome (Fig. 6d). The inner epidermis formed short unicellular papillae with a smooth surface (Fig. 6d). They were highly vacuolated, not glandular.

\section{Utricularia bremii (Fig. 7a-f)}

The spur was shortly conical. In the lateral view, it was about as wide as long. Glandular trichomes densely covered the internal ventral spur surface (Fig. 7a, b). There was glandular continuity between the palate and the spur (Fig. 7a). In the transverse section, the wall of the spur was composed of several cell layers: the internal epidermis, a few layers of parenchyma cells and the outer epidermis (Fig. 7c). The parenchyma cells were highly vacuolated and non-glandular. Intercellular spaces occurred between the parenchyma cells. The parenchyma cells contained numerous plastids with large starch grains. Collateral vascular bundles occurred in the ground parenchyma (Fig. 7c, d), and each contained both xylem and phloem elements. The inner epidermis formed short unicellular papillae with striations on the surface (Fig. 7b). The papillae had rounded tips. They were highly vacuolated and contained plastids with starch.

The glandular spur trichomes were composed of a single basal cell, a unicellular short pedestal cell (barrier cell with a thick radial wall impregnated with cutin, mean

Fig. 6 General floral morphology and spur structure of Utricularia australis. a Floral morphology of $U$. australis (Australian population) from the collection of aquatic carnivorous plants in the Institute of Botany at Třeboň: spur (arrow). b Part of the section through the spur with glandular trichomes and papillae: pedestal cell (arrow), basal cell (Bc), papilla (p), parenchyma cell (pa), intercellular spaces (star), external epidermis (ep); bar $=20 \mu \mathrm{m}$. c Nectar trichome distribution inside the spur; bar $=1 \mathrm{~mm}$. d Morphology of nectar trichomes and papillae; note that one trichome had a three-celled stalk; additional cell (arrow), swollen cuticle of the head cells (star); bar $=50 \mu \mathrm{m}$
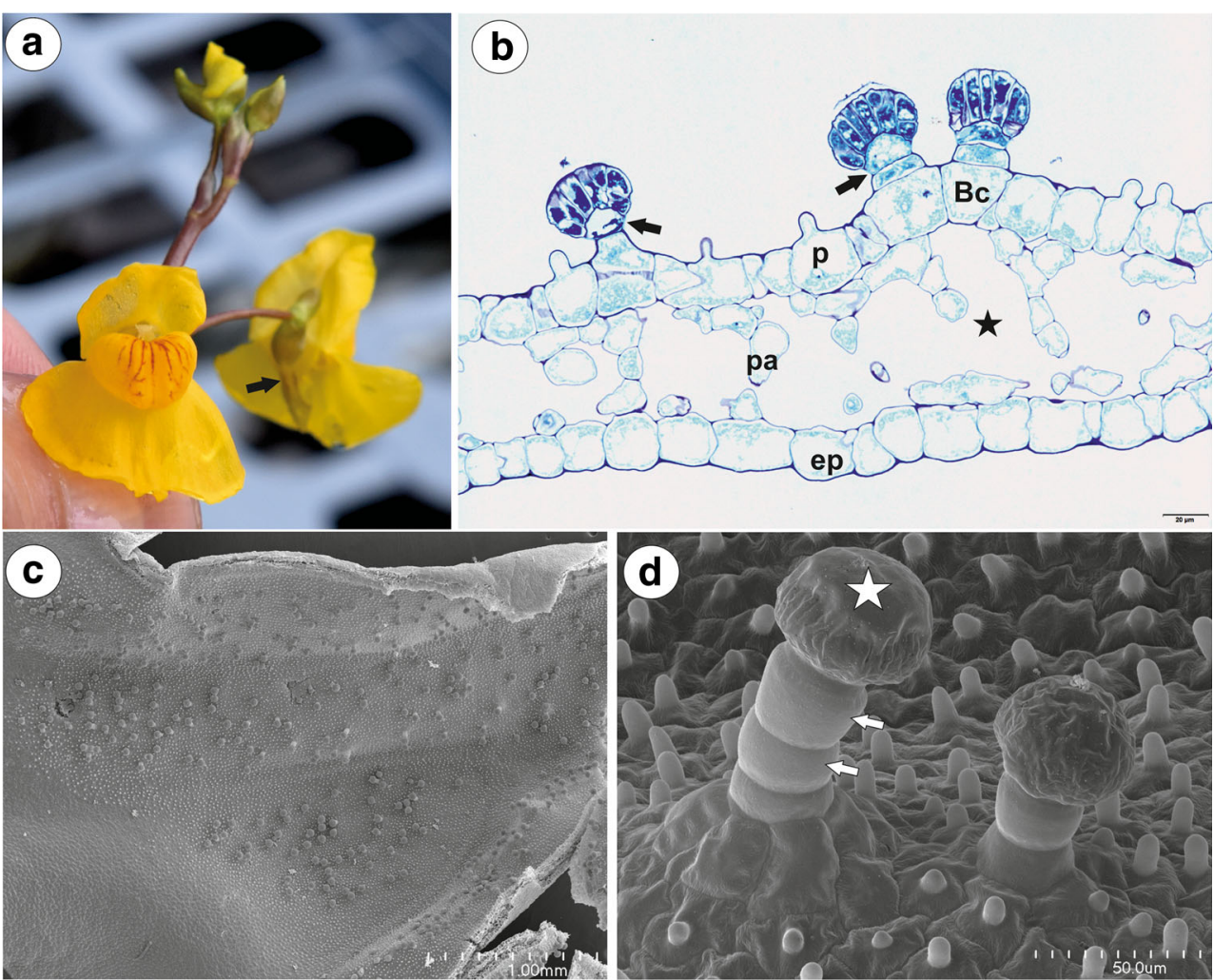
Fig. 7 General morphology and anatomy of Utricularia bremii spur. a General morphology of the lower corolla lip: palate (P), throat $\operatorname{spur}(\mathrm{S})$; bar $=1 \mathrm{~mm}$. b Morphology of nectar spur trichomes and papillae; bar = $30 \mu \mathrm{m}$. c General anatomy of the spur: vascular bundle $(\mathrm{Vb})$; bar $=$ $50 \mu \mathrm{m}$. d Part of the section through the spur showing structure of trichome and vascular bundle: separated cuticle from the head cells (black arrow), pedestal cell $(\mathrm{Pc})$, basal cell $(\mathrm{Bc})$, xylem elements $(\mathrm{x})$, phloem $(\mathrm{Ph})$; bar $=$ $20 \mu \mathrm{m}$. e, f Ultrastructure of head cells; note the paracrystalline protein inclusion (star) in the nucleus $(\mathrm{N})$, dense cytoplasm with mitochondria (m). In the vacuoles $(\mathrm{V})$, there are flocculent electron-dense material and myelin-like figures. Cell-wall ingrowths (arrows) are on the inner surface of the outer wall but also on the inner walls between the terminal cells; thick cuticle (c); bar $=1.1 \mu \mathrm{m}(\mathbf{e})$ and bar $=$ $1 \mu \mathrm{m}(\mathbf{f})$
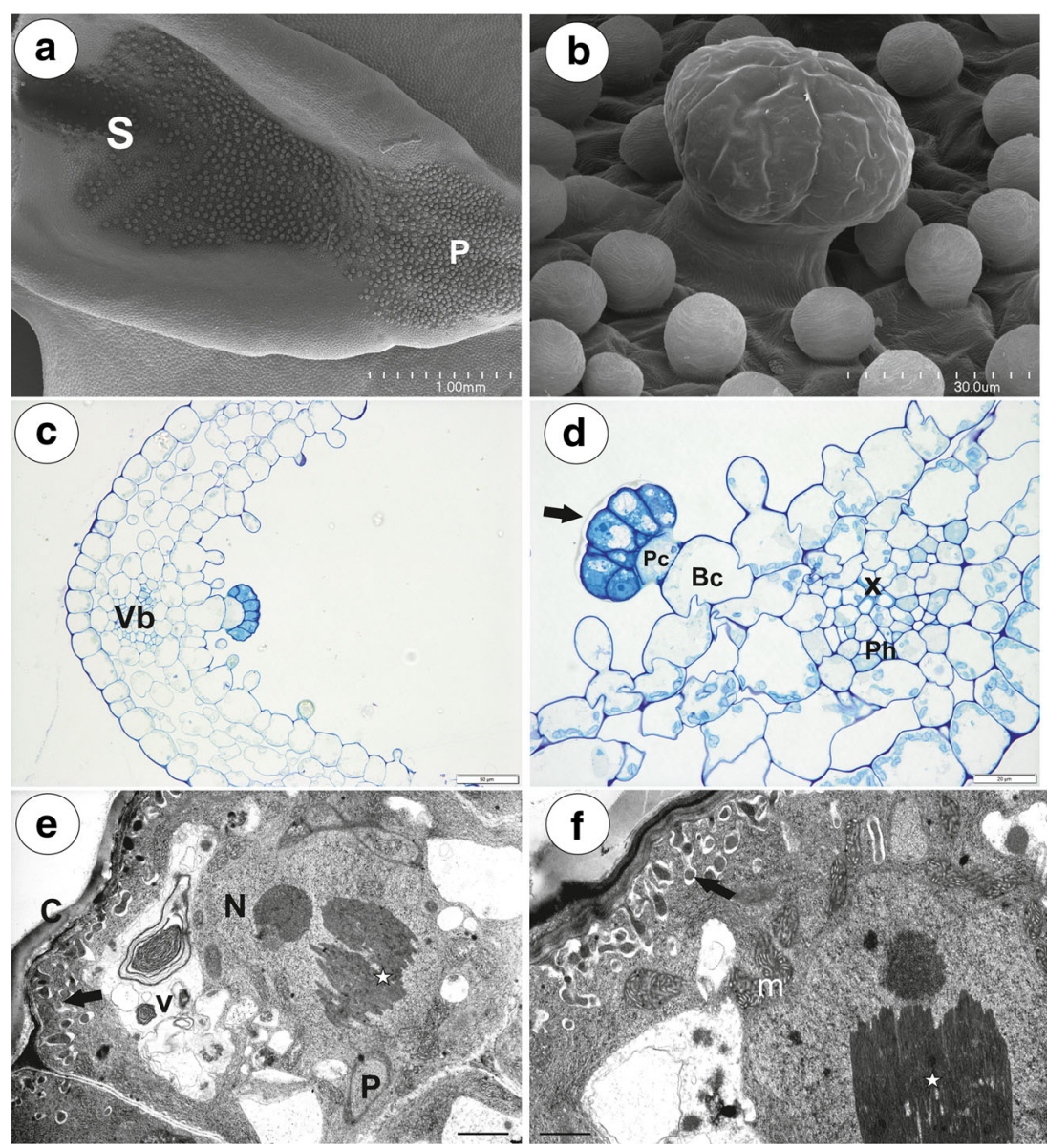

length $=16 \mu \mathrm{m}, n=10$ ) and a multi-celled head (mean diameter $=42 \mu \mathrm{m}, n=10$; Fig. $7 \mathrm{~d}$ ). The basal cell was highly vacuolated, and the lateral wall of this cell lay partly embedded in the epidermis. Its outer part, which formed a short "stalk", created a well-developed cuticle that was continuous with that of the epidermal cells and the cuticular deposits of the pedestal cell. The head cells were transfer cells. Cell wall ingrowths (reticulate type) occurred on the inner surface of the outer wall of the terminal (head) cells, but also on the inner walls between the terminal cells (Fig. 7e, f). The cytoplasm of the head cells of the glandular trichomes stained deeply with methylene blue/azure II (Fig. 7d). The protoplasts of the head cells were electron-dense and had a prominent nucleus containing a paracrystalline protein inclusion. Their vacuole contained myelin-like figures and flocculent electron-dense material (Fig. 7e, f). Plastids were common and contained an electron-dense stroma; some of them were cube- or amoeboid-shaped (Fig. 7e). Mitochondria with well-developed cristae (Fig. 7f) and profiles of rough endoplasmic reticulum (RER) occurred in the cytoplasm. The thick cuticle frequently became distended and separated from the cell walls of the head cells, especially in the apical part of the cells in response to the subcuticular accumulation of the nectar.

\section{Utricularia foliosa (Figs. 8 and 9)}

The spur was narrowly conical, nearly parallel with the lower lip (Fig. 8a). Nectariferous trichomes occurred mainly in two patches (Fig. 8b). Trichomes were also rarely scattered on the opposite spur surface. In the transverse section, the spur wall was composed of several cell layers: the internal epidermis, a few layers of parenchyma cells and the outer epidermis (Fig. $8 \mathrm{c}, \mathrm{d})$. The parenchyma cells were highly vacuolated and nonglandular. Intercellular spaces occurred between the parenchyma cells. Six collateral vascular bundles were found in the parenchyma. Groups of glandular trichomes occurred between the places where vascular bundles were localised (Fig. 8c), but they were sometimes found above the vascular bundle (Fig. 8e). The sessile glandular spur trichomes were composed of a single basal cell, a unicellular short pedestal cell (barrier cell with a thick radial wall impregnated with cutin) and a multi-celled head. The head cells were transfer cells (not shown). The inner spur epidermis formed conical papillae with cuticular striations (Fig. 8f). 
Fig. 8 General floral morphology and spur structure of Utricularia foliosa. a Floral morphology of U. foliosa: spur (arrow). b Nectar trichome distribution inside the spur; bar $=500 \mu \mathrm{m}$. c General anatomy of the spur: vascular bundle $(\mathrm{Vb})$; bar $=100 \mu \mathrm{m}$. d Part of the section through the spur showing structure of trichome: pedestal cell $(\mathrm{Pc})$, basal cell $(\mathrm{Bc})$; bar $=20 \mu \mathrm{m}$. e Occurrence of a nectar trichome near the vascular bundle; bar $=10 \mu \mathrm{m}$. f

Morphology of nectar trichomes and papillae; $b a r=50 \mu \mathrm{m}$
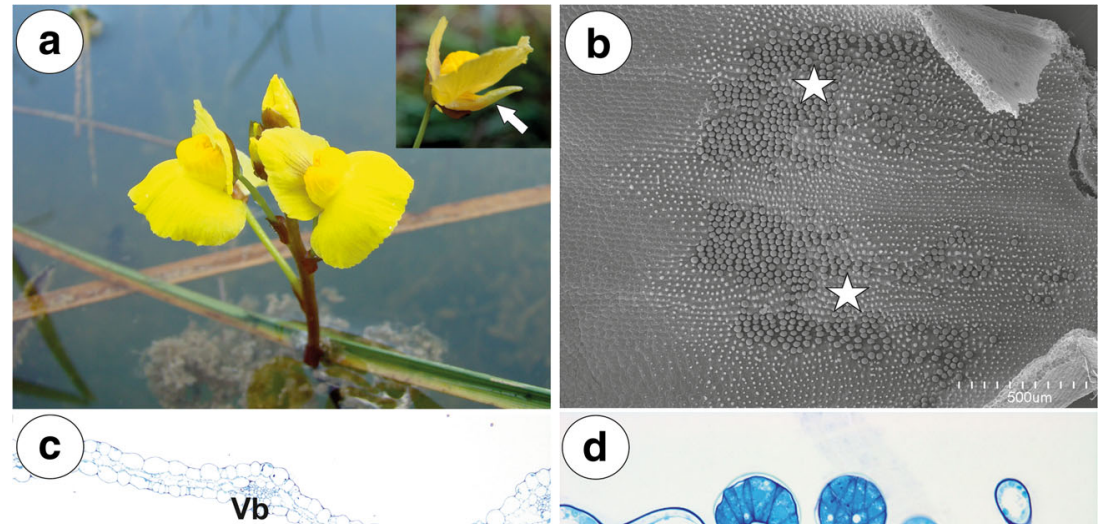

d

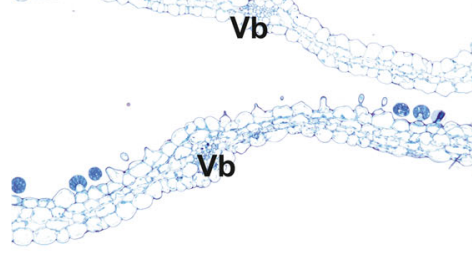

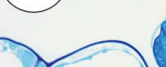

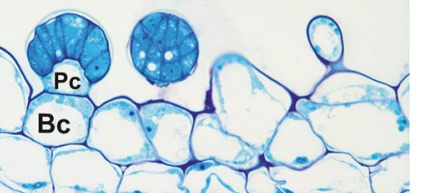

$\mathrm{Vb}$
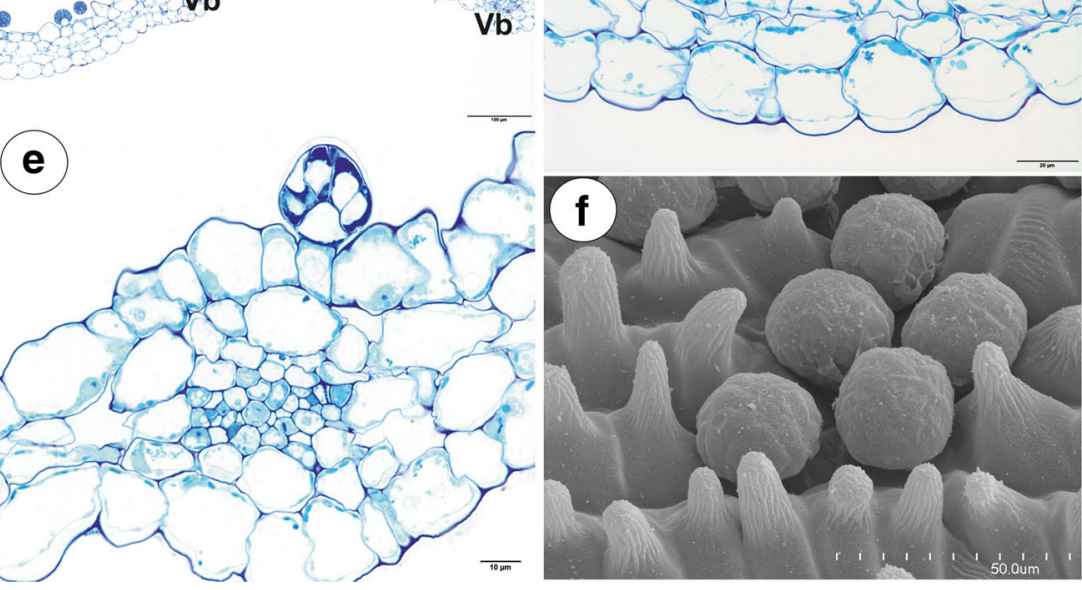

(1)

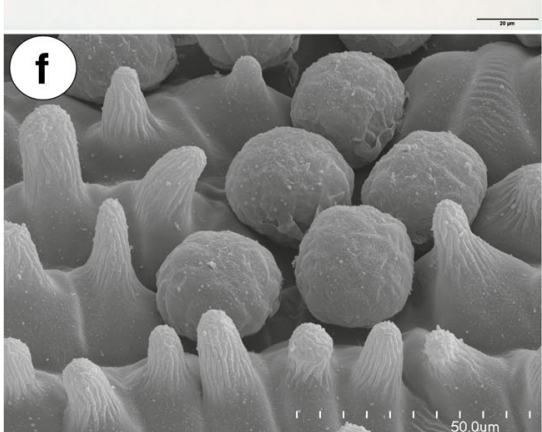

\section{Floral visitors and pollinators}

Utricularia foliosa flowers were visited by two species of small Halictidae bees (Fig. 9a-c) which penetrated the palate and the corolla tube (Fig. 9b). Utricularia pollen grains were visible on the surface of the bee thorax (Fig. 9a).

\section{Discussion}

Spur trichomes of Utricularia have been analysed for a long time - mainly for the potential taxonomic use (e.g. Faroog 1963; Farooq and Siddiqui 1966; Thor 1988; Taylor 1989). To date, however, no data have been published on the
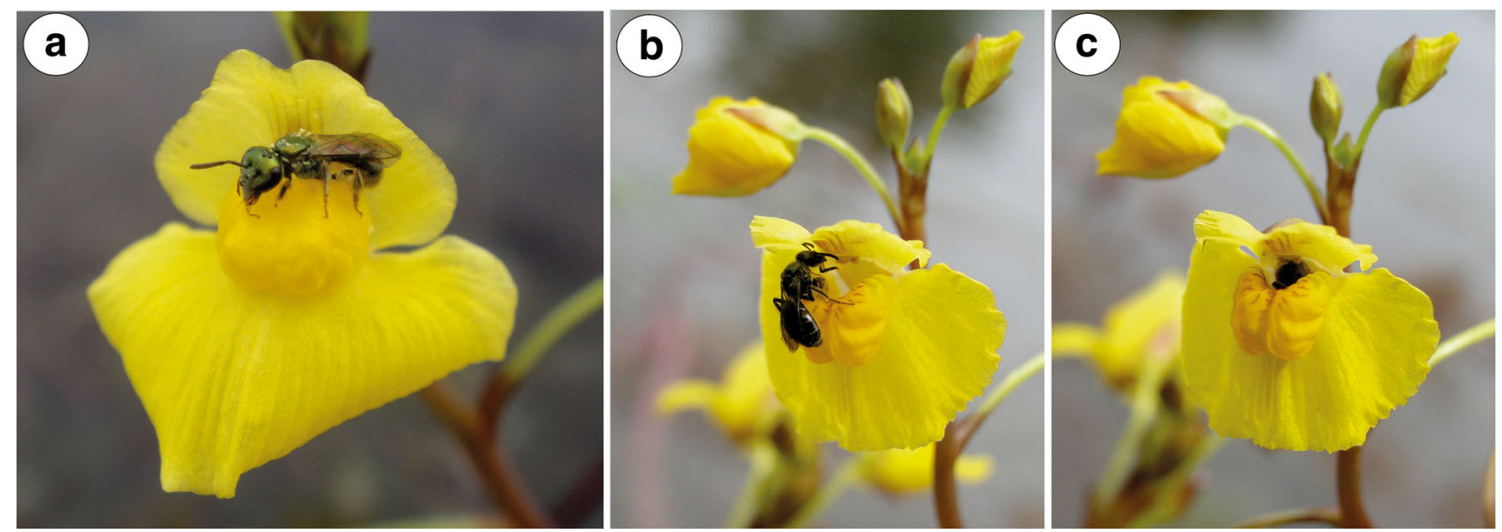

Fig. 9 Pollination of Utricularia foliosa. a-c Behaviour of bees on $U$. foliosa flowers; note pollen grains on the bee thorax. (Credit of images: Dasmiliá Cruz) 
ultrastructure of spur nectary trichomes of Utricularia. All species examined here had the capitate trichome type with the single-barrier cell in the spur. The interspecific differences included the stalk length (these trichomes were sessile in $U$. foliosa, in $U$. bremii nearly sessile in contrast to wellstalked trichomes in $U$. vulgaris and $U$. australis) and the occurrence of the additional cell or cells in the stalk (U. vulgaris, U. australis). Płachno et al. (2017b) suggested that the general structure of the nectar-secreting trichomes in the genus Utricularia were very conservative in evolutionary terms, and results obtained here also corroborate this hypothesis. In all examined species in this study, the spur epidermis completely lacked nectary stomata and papillae were not glandular, either. Thus, the only source of nectar is the glandular capitate trichomes. Trichome head cells have ultrastructure typical for nectary glandular cells (see e.g. Fahn 1979a, b; Durkee 1983; Razem and Davis 1999; Wist and Davis 2006; Nepi 2007). However, it should be underlined that the most published observations were performed on the non-trichome nectarines, and data about trichome nectary ultrastructure are scarce and based on a few taxa only (Lonicera-Fahn and Rachmilevitz 1970; Abutilon-Robards and Stark 1988; Hibiscus-Sawidis et al. 1987, 1989; PlatantheraStpiczyńska et al. 2005; Cyclanthera-Nepi 2007; Adenocalymma-Gama et al. 2016). In nectar-secreting trichromes, e.g. in Abutilon or Hibiscus, granulocrine secretion type was suggested (Kronestedt-Robards et al. 1986; Sawidis et al. 1987, 1989; Robards and Stark 1988; Kronestedt-Robards and Robards 1991). In head cells, we observed neither a "secretory reticulum" nor a hypertrophied Golgi apparatus. Moreover, the occurrence of cell wall ingrowths in the head cells may be evidence that the nectar is transported via an eccrinous mode of secretion (see Lüttge 1971; Nepi 2007).

The ultrastructural characters of the examined trichomes are very similar when compared with the scent glands from the palate of $U$. bremii (Płachno et al. 2017a) and the corolla appendages of $U$. dunlopii (Płachno et al. 2016). In all Utricularia species examined here, the nectary trichome had a barrier cell (pedestal cell) with a thick radial wall, which was impregnated with a lipophilic material. The endoderm-like element is typical for extranuptial nectaries devoid of stomata (see Paiva 2017 and literature therein). According to Cardoso-Gustavson and Davis (2015), cells impregnated with lipophilic compounds in the anticlinal walls not only act as a barrier to reduce an apoplastic route of outflow, but also control the inflow from the extracellular environment into actively secreting nectary tissues in floral trichome nectaries. However, it should be added that the barrier cell is the common character of various secretory trichomes of Lentibulariaceae (e.g. Fineran and Lee 1975;
Fineran and Gilbertson 1980; Fineran 1985; Płachno et al. 2007, 2017a).

Based on our anatomical and ultrastructural observations and recent knowledge of the functioning of the nectaries (for details see Nepi 2007), we propose a way of nectar formation and secretion in Utricularia. Carbohydrates produced in tissues other than the spur are transported via vascular bundles to the spur parenchyma and epidermis cells and stored as starch. After starch hydrolysis, this pre-nectar is transported via the apoplast and the symplast from parenchyma and epidermis cells to the basal cell of the trichome. If there is an additional cell, this cell mediates the transport between the basal and barrier cells. The pre-nectar is transported between the basal and pedestal cell only via symplast as the radial wall of the barrier cell is impregnated and acts as a hydrophobic barrier. Also, the pre-nectar has to be transported only via symplast from the pedestal cell to the head cells. The pre-nectar is then transformed into nectar in the head cells. As these cells are transfer cells, the nectar secretion should be eccrine. Then, the nectar is accumulated in the subcuticular space and released via cuticle pores.

Even though the spur of $U$. bremii had a different size and shape (see Taylor 1989) from the other examined species of the same Utricularia section, the general anatomy of the spur was the same. However, there were some differences between species in the internal spur epidermis microsculpture, which may relate to specialisation for insect visitors/pollinators. All examined species were different from each other in the nectary trichome distribution at the spur surface: $U$. vulgaris (on the internal abaxial side of the spur), $U$. australis (on both the abaxial and adaxial side), U. bremii (on the internal abaxial side) and U. foliosa (in two oblong patches; Thor 1988; Taylor 1989 and our observations). The close localisation of the nectar trichomes near the vascular bundles in $U$. foliosa is probably due to shortening the route of sugar transport from the phloem to the nectary tissue or to an increased water demand for the nectar production. A similar connection between nectar trichome localisation and vascular tissue was recorded in the $U$. nelumbifolia spur, where the trichome distribution in some parts of the spur coincided with the position of the vascular bundles (Płachno et al. 2017b: Fig. 12A). According to Silva et al. (2018), the generic section Utricularia is subdivided into two major clades, one formed by U. floridana, U. gibba and $U$. striata (clade I) and the other one (clade II) by the remaining species including those analysed here. However, $U$. foliosa is phylogenetically the most distant species within clade II, nesting outside the core of the section Utricularia. Utricularia vulgaris is most related with $U$. australis, and this fact is also reflected in the nectar trichome structure.

We found that the examined species differed in the micromorphology of papillae in the spurs. Papillae with striations occurred in $U$. bremii and $U$. foliosa, whereas only smooth papillae were observed in $U$. australis and $U$. vulgaris. Also, 
$U$. bremii had papillae with rounded tips in contrast to other species. Unfortunately, there is only scarce literature information on the micromorphology of papillae in Utricularia spurs; papillae with striations were recorded in $U$. dunlopii and U. dichotoma (section Pleiochasia; Płachno et al. 2016), $U$. reniformis (Clivati et al. 2014), U. nelumbifolia and $U$. cornigera (Płachno et al. 2017b; formerly sect. Iperua, now included in sect. Orchidioides, see Rodrigues et al. 2017). Thus, it is difficult to draw any evolutionary conclusions. Various papillae sizes and surface morphology (with smooth surface versus papillae with striations) may provide "tactile information" for particular pollinators. According to Kevan and Lane (1985), honeybees are able to detect, learn and discriminate between the microsculptured epidermis of flower petals. The microsculptural patterns can be used as nectar guides by foraging insects. Bell et al. (2009) proposed that the occurrence of papillae in spurs of deceit-pollinated orchids may improve pollination because papillae satisfy the tactile expectation of pollinating insects. The occurrence of papillae in Utricularia spurs may also have another explanation. Papillae form a hydrophobic surface and so, plants may produce less nectar. This explanation is in an agreement with the observation of Hobbhahn et al. (2006) who recorded extremely small volumes of nectar in spurs of some terrestrial Utricularia species. These authors also observed that nectar did not accumulate in the tip of the spur but adhered in small droplets to the inner spur walls. We have made a similar observation in $U$. vulgaris. Thus, these micro-droplets are formed on a single trichome head or a group of trichomes. However, Clivati et al. (2014) observed that in the $U$. reniformis spur, nectar occurred as droplets but it also reached down to the spur tip.

Taylor (1989) mentioned Hymenoptera, Diptera, Lepidoptera and hummingbirds as visitors to Utricularia flowers. Hobbhahn et al. (2006) observed that more than 50 species of bees, butterflies, moths, hawk moths and dipterans visited and pollinated the flowers of three terrestrial Utricularia species belonging to the subgenus Bivalvaria.

Even though Utricularia vulgaris is not only farranging but also one out of the best known Utricularia species, the literature is lacking both pollination biology studies and reports of pollinator observations. In general, observations of pollinators or flower visitors of Utricularia species from the section Utricularia are scarce. Araki and Kadono (2003) mentioned that Japanese Utricularia australis (probably this was $U$. tenuicaulis Miki) was pollinated "by small insects, such as aphids or small dipterous species". However, these authors did not add any details or documentations, which might prove that these insects were pollinators. An aphid Rhopalosiphum nymphaeae was recorded as a pest on Utricularia spp. by various authors (see e.g. Center et al. 1999), but we have observed that aphids mainly occupy external parts of inflorescence. Honda (2007) observed that flowers of Utricularia macrorhiza (closely related to $U$. vulgaris) were visited and pollinated by a member of the Syrphidae family, which was determined as Helophilus intentus (see http://pollinator.org/shop/ poster-15). Helophilus behaviour on the U. macrorhiza flower reminds that instead one of Eristalis tenax on $U$. vulgaris flowers. Westerkamp and Classen-Bockhoff (2007) and later also Clivati et al. (2014) classified Utricularia as having gullet-shaped flowers. In this type of flower, reproductive structures are located in the upper side of the corolla and, consequently, the pollen grains become attached to the pollinator's back-nototribic transfer (Faegri and van der Pijl 1971). We documented the nototribic transfer in $U$. vulgaris because we found Utricularia pollen grains at the Eristalis back. However, pollen grains were also found at other insect parts (e.g. near eyes) and this is due to that the fly cleaned its body surface after penetrating the flower.

Salmon (2001) mentioned small honey bees as pollinators of Utricularia gibba L., however, without any details on the pollination biology. Płachno et al. (2017a) observed that small Hymenoptera (members of families Mymaridae and Braconidae) were flower visitors of $U$. bremii. They suggested that these Hymenoptera might also be pollinators of $U$. minor, which has a similar size and flower structure to those of $U$. bremii.

Both $U$. vulgaris and $U$. foliosa flowers were visited by small Halictidae bees. As we did not observe $U$. vulgaris pollen grains on the surface of the Lasioglossum bee head and thorax, we propose that this bee is only a flower visitor in contrast with the true pollinator Eristalis tenax fly. However, in $U$. foliosa, the small Halictidae bees seem to be pollinators of this species.

\section{Conclusions}

Nectar in Utricularia flowers is produced by capitate spur trichomes and despite the various spur morphology, the trichomes have similar architecture and ultrastructure. The head cells of these trichomes are transfer cells with an eccrine nectar secretion. As the flower spur in Utricularia is the organ where nectar is produced and stored, it should be considered nectary.

Acknowledgements Sincere thanks are due to Prof. Karina Wieczorek for aphid species determination and to Dr. Brian G. McMillan, Glasgow, Scotland, UK, for English correction.

Funding information A part of equipment used in this study was funded by the National Science Centre, Poland (contract grant number DEC2013/09/B/NZ8/03308 in case BJP). This research was supported financially by the Ministry of Science and Higher Education of Poland as a part of the statutory activities of the Department of Plant Cytology and 
Embryology, Jagiellonian University in Kraków, and partly also by the Czech Long-term research development project No. RVO 67985939 (for LA).

\section{Compliance with ethical standards}

Conflict of interest The authors declare that they have no conflict of interest.

Open Access This article is distributed under the terms of the Creative Commons Attribution 4.0 International License (http:// creativecommons.org/licenses/by/4.0/), which permits unrestricted use, distribution, and reproduction in any medium, provided you give appropriate credit to the original author(s) and the source, provide a link to the Creative Commons license, and indicate if changes were made.

\section{References}

Abrahamczyk S, Kessler M, Hanley D, Karger DN, Müller MPJ, Knauer AC, Keller F, Schwerdtfeger M, Humphreys AM (2017) Pollinator adaptation and the evolution of floral nectar sugar composition. $\mathrm{J}$ Evol Biol 30(1):112-127. https://doi.org/10.1111/jeb.12991

Adamec L, Poppinga S (2016) Measurement of the critical negative pressure inside traps of aquatic carnivorous Utricularia species. Aquat Bot 133:10-16. https://doi.org/10.1016/j.aquabot.2016.04.007

Araki S, Kadono Y (2003) Restricted seed contribution and clonal dominance in a free-floating aquatic plant Utricularia australis $\mathrm{R}$. Br. in southwestern Japan. Ecol Res 18(5):599-609. https://doi.org/10. 1046/j.1440-1703.2003.00581.x

Bell AK, Roberts DL, Hawkins JA, Rudall PJ, Box MS, Bateman RM (2009) Comparative morphology of nectariferous and nectarless labellar spurs in selected clades of subtribe Orchidinae (Orchidaceae). Bot J Linn Soc 160(4):369-387. https://doi.org/10. 1111/j.1095-8339.2009.00985.x

Box MS, Dodsworth S, Rudall PJ, Bateman RM, Glover BJ (2011) Characterization of Linaria KNOX genes suggests a role in petalspur development. Plant J 68(4):703-714. https://doi.org/10.1111/j. 1365-313X.2011.04721.x

Cardoso-Gustavson P, Davis AR (2015) Is nectar reabsorption restricted by the stalk cells of floral and extrafloral nectary trichomes? Plant Biol 17(1):134-146. https://doi.org/10.1111/plb.12208

Center TD, Dray FA, Jubinsky GP, Grodowitz M (1999) Insects and other arthropods that feed on aquatic and wetland plants. U.S. Department of Agriculture, Agricultural Research Service, Technical Bulletin 1870 , p. 200

Clivati D, Cordeiro GD, Płachno BJ, Miranda VFO (2014) Reproductive biology and pollination of Utricularia reniformis A.St.-Hil. (Lentibulariaceae). Plant Biol 16(3):677-682. https://doi.org/10. 1111/plb.12091

Darwin C (1862) The various contrivances by which orchids are fertilized by insects. John Murray, London

Durkee LT (1983) Ultrastructure of nectaries. In: Bentley B, Thomas E. (eds) the biology of nectaries. Columbia University Press, New York, pp 1-29

Fahn A (1979a) Secretory tissues in plants. Academic Press, London

Fahn A (1979b) Ultrastructure of nectaries in relation to nectar secretion. Am J Bot 66(8):977-985. https://doi.org/10.2307/2442240

Fahn A, Rachmilevitz T (1970) Ultrastructure and nectar secretion in Lonicera japonica. In: Robson NKB, Cutler DF, Gregory M (eds) New research in in plant anatomy. Academic Press, London, pp 5156
Faegri K, van der Pijl L (1971) The principles of pollination ecology. Pergamon Press, New York

Farooq M (1963) Trichomes on the floral parts of Utricularia. J Indian Bot Soc 45:242-248

Farooq M, Siddiqui SA (1966) Trichomes on the flowers of Utricularia. Beitr Biol Pflanzen 42:353-361

Fineran BA (1985) Glandular trichomes in Utricularia: a review of their structure and function. Isr J Bot 34:295-333

Fineran BA, Lee MSL (1975) Organization of quadrifid and bifid hairs in the trap of Utricularia monanthos. Protoplasma 84(1-2):43-70. https://doi.org/10.1007/BF02075942

Fineran BA, Gilbertson JM (1980) Application of lanthanum and uranyl salts as tracers to demonstrate apoplastic pathways for transport in glands of the carnivorous plant Utricularia monanthos. Euro J Cell Biol 23:66-72

Gama TSS, Aguiar-Dias ACA, Demarco D (2016) Transfer cells in trichomatous nectary in Adenocalymma magnificum (Bignoniaceae). An Acad Bras Cienc 88(1 Suppl):527-537. https://doi.org/10.1590/0001-3765201620140606

Hobbhahn N, Küchmeister H, Porembski S (2006) Pollination biology of mass flowering terrestrial Utricularia species (Lentibulariaceae) in the Indian western Ghats. Plant Biol 8:791-804

Hodges SA (1997) Floral nectar spurs and diversification. Int J Plant Sci 158:81-88

Hodges SA, Arnold ML (1995) Spurring plant diversification: are floral nectar spurs a key innovation? Proc R Soc Lond B 262(1365):343348. https://doi.org/10.1098/rspb.1995.0215

Honda M (2007) http://www.honda-e.com/CP ARTICLES/ UmacrorhizaPollinator.htm

Humphrey C, Pittman G (1974) A simple methylene blue-azure II-basic fuchsin for epoxy-embedded tissue sections. Stain Technol 49(1):914. https://doi.org/10.3109/10520297409116929

Jérémie J (1989) Autogamie dans le genre Utricularia L. (Lentibulariaceae). Bull Mus Nat Hist Nat Sect B, Adansonia 1: $17-28$

Kevan PG, Lane MA (1985) Flower petal microtexture is a tactile cue for bees. Proc Natl Acad Sci U S A 82(14):4750-4752. https://doi.org/ 10.1073/pnas.82.14.4750

Kronestedt-Robards EC, Robards AW, Strak M, Olesen P (1986) Development of trichomes in the Abutilon nectary gland. Nord J Bot 6:627-639

Kronestedt-Robards EC, Robards AW (1991) Exocytosis in gland cells. In: Hawes CR, Coleman JOD, Evans DE (eds) Endocytosis, exocytosis, and vesicle traffic in plants. Cambridge University Press, Cambridge, U.K., pp 199-231

Lüttge U (1971) Structure and function of plant glands. Ann Rev Plant Physiol 22(1):23-44. https://doi.org/10.1146/annurev.pp.22. 060171.000323

Lowrie A, Cowie ID, Conran JG (2008) A new species and section of Utricularia (Lentibulariaceae) from northern Australia. Telopea 12: $31-46$

Nepi M (2007) Nectary structure and ultrastructure. In: Nicolson SW, Nepi M, Pacini E (eds) Nectaries and nectar. Springer, Rotterdam, pp 129-166. https://doi.org/10.1007/978-1-4020-5937-7_3

Paiva EAS (2017) How does the nectar of stomata-free nectaries cross the cuticle? Acta Bot Bras 31(3):525-530. https://doi.org/10.1590/ 0102-33062016abb0444

Płachno BJ, Kozieradzka-Kiszkurno M, Świątek P (2007) Functional utrastructure of Genlisea (Lentibulariaceae) digestive hairs. Ann Bot 100:195-203

Płachno BJ, Stpiczyńska M, Świątek P, Davies KL (2016) Floral micromorphology of the Australian carnivorous bladderwort Utricularia dunlopii, a putative pseudocopulatory species. Protoplasma 253(6): 1463-1473. https://doi.org/10.1007/s00709-015-0900-8

Płachno BJ, Stpiczyńska M, Krajewski Ł, Światek P, Adamec L, Miranda VFO (2017a) Flower palate structure of the aquatic bladderworts 
Utricularia bremii Heer and U. minor L. from section Utricularia (Lentibulariaceae). Protoplasma 254(5):2007-2015. https://doi.org/ 10.1007/s00709-017-1097-9

Płachno BJ, Stpiczyńska M, Davies KL, Świątek P, Miranda VFO (2017b) Floral ultrastructure of two Brazilian aquatic-epiphytic bladderworts: Utricularia cornigera Studnička and $U$. nelumbifolia Gardner (Lentibulariaceae). Protoplasma 254(1): 353-366. https://doi.org/10.1007/s00709-016-0956-0

Puzey JR, Gerbode SJ, Hodges SA, Kramer EM, Mahadevan L (2012) Evolution of spur-length diversity in Aquilegia petals is achieved solely through cell-shape anisotropy. Proc R Soc B 279(1733): 1640-1645. https://doi.org/10.1098/rspb.2011.1873

Razem FA, Davis AR (1999) Anatomical and ultrastructural changes of floral nectary of Pisum sativum L. during flower development. Protoplasma 206(1-3):57-72. https://doi.org/10.1007/BF01279253

Reynolds ES (1963) The use of lead citrate at high $\mathrm{pH}$ as an electronopaque stain for electron microscopy. J Cell Biol 17(1):208-212. https://doi.org/10.1083/jcb.17.1.208

Robards AW, Stark M (1988) Nectar secretion in Abutilon: a new model. Protoplasma 142(2-3):79-91. https://doi.org/10.1007/BF01290866

Rodrigues FG, Marulanda NF, Silva SR, Płachno BJ, Adamec L, Miranda VFO (2017) Phylogeny of the 'orchid-like' bladderworts (gen. Utricularia sect. Orchidioides and Iperua: Lentibulariaceae) with remarks on the stolon-tuber system. Ann Bot 120(5):709-723. https://doi.org/10.1093/aob/mcx056

Sawidis T, Eleftheriou EP, Tsekos I (1987) The floral nectaries of Hibiscus rosasinensis L. II Plasmodesmatal frequences Phyton 27: 155-164

Sawidis T, Eleftheriou EP, Tsekos I (1989) The floral nectaries of Hibiscus rosasinensis III. A morphometric and ultrastructural approach. Nord J Bot 9(1):63-71. https://doi.org/10.1111/j.17561051.1989.tb00987.x

Salmon B (2001) Carnivorous plants of New Zealand. Ecosphere Publications

Silva SR, Gibson R, Adamec L, Domínguez Y, Miranda VFO (2018) Molecular phylogeny of bladderworts: a wide approach of Utricularia (Lentibulariaceae) species relationships based on six plastidial and nuclear DNA sequences. Mol Phylogen Evol 118: 244-264

Stpiczyńska M, Milanesi C, Faleri C, Cresti M (2005) Ultrastructure of the nectary spur of Platanthera chlorantha (Custer) Rchb. (Orchidaceae) during successive stages of nectar secretion. Acta Biol Cracov 47:111-119

Taylor P (1989) The genus Utricularia - a taxonomic monograph. Kew Bull Addit Ser 14:1-724

Thor G (1988) The genus Utricularia in the Nordic countries, with special emphasis on Utricularia stygia and Utricularia ochroleuca. Nord J Bot 8(3):213-225. https://doi.org/10.1111/j.1756-1051. 1988.tb01713.x

Westerkamp C, Classen-Bockhoff R (2007) Bilabiate flowers: the ultimate response to bees? Ann Bot 100(2):361-374. https://doi.org/10. 1093/aob/mcm 123

Whittall JB, Hodges SA (2007) Pollinator shifts drive increasingly long nectar spurs in columbine flowers. Nature 447(7145):706-709. https://doi.org/10.1038/nature05857

Wist TJ, Davis AR (2006) Floral nectar production and nectary anatomy and ultrastructure of Echinacea purpurea (Asteraceae). Ann Bot 97(2):177-193. https://doi.org/10.1093/aob/mcj027 